This document was prepared in conjunction with work accomplished under Contract No. DE-AC09-96SR18500 with the U.S. Department of Energy.

This work was prepared under an agreement with and funded by the U.S. Government. Neither the U. S. Government or its employees, nor any of its contractors, subcontractors or their employees, makes any express or implied: 1 . warranty or assumes any legal liability for the accuracy, completeness, or for the use or results of such use of any information, product, or process disclosed; or 2 . representation that such use or results of such use would not infringe privately owned rights; or 3 . endorsement or recommendation of any specifically identified commercial product, process, or service. Any views and opinions of authors expressed in this work do not necessarily state or reflect those of the United States Government, or its contractors, or subcontractors. 
WSRC-STI-2007-00060

Keywords: hydrogen, platinum, palladium

\section{Catalyst Evaluation for a Sulfur Dioxide-Depolarized Electrolyzer}

Héctor R. Colón-Mercado and David T. Hobbs*

Savannah River National Laboratory

Washington Savannah River Company

Savannah River Site

Aiken, SC 29808

Submitted as a technical paper to

Electrochemical and Solid-State Letters

JANUARY 2007

*Corresponding author

E-mail: david.hobbs@srnl.doe.gov 


\title{
Catalyst Evaluation for a Sulfur Dioxide-Depolarized Electrolyzer
}

\author{
Héctor R. Colón-Mercado and David T. Hobbs*
}

\author{
Savannah River National Laboratory \\ Washington Savannah River Company \\ Savannah River Site \\ Aiken, SC 29808
}

\begin{abstract}
Thermochemical processes are being developed to provide global-scale quantities of hydrogen. A variant on sulfur-based thermochemical cycles is the Hybrid Sulfur (HyS) Process which uses a sulfur dioxide depolarized electrolyzer (SDE) to produce the hydrogen. Testing examined the activity and stability of platinum and palladium as the electrocatalyst for the SDE in sulfuric acid solutions. Cyclic and linear sweep voltammetry revealed that platinum provided better catalytic activity with much lower potentials and higher currents than palladium. Testing also showed that the catalyst activity is strongly influenced by the concentration of the sulfuric acid electrolyte.
\end{abstract}

\section{INTRODUCTION}

Concerns about the dependence on petroleum imports, poor air quality, and greenhouse emissions have accelerated the development of energy systems using hydrogen as an energy carrier. Hydrogen can be extracted using a variety of technologies, which can be divided in three main categories: thermal, electrochemical, and biological. Among the production methods water electrolysis is a well established technology, which is capable of producing emission free hydrogen if used in conjunction with renewable or nuclear energy [1]. However, the technology and energy inputs for the electrolysis process can make the production of hydrogen by this method expensive. In order to produce global scale quantities of hydrogen in a more energy efficient process, thermochemical water splitting cycles using heat from a nuclear reactor have been proposed and developed since the late 1960s[2]. Among the many possible thermochemical cycles for the production of hydrogen, the sulfur-based cycles lead the competition in overall energy efficiency.

A variant on sulfur-based thermochemical cycles is the Hybrid Sulfur (HyS) Process. The HyS cycle uses a sulfur dioxide-depolarized electrolyzer (SDE) to produce hydrogen. The electrolyzer oxidizes sulfur dioxide to form sulfuric acid at the anode [r1] and reduces protons to form hydrogen at the cathode [r2]. The overall electrochemical cell reaction consists of the production of $\mathrm{H}_{2} \mathrm{SO}_{4}$ and $\mathrm{H}_{2}$ [r3]. The key attribute of the reactions occurring in the SDE is the anodic reaction [r1], which occurs at a standard half cell potential of $-0.158 \mathrm{~V}$ vs. standard hydrogen electrode (SHE) [3]. Compared with low temperature pure water electrolysis, which occurs at $-1.23 \mathrm{~V}$ vs. SHE, the SDE could potentially produce the same amount of hydrogen with almost one eighth of the current used in conventional electrolysis. 


$$
\begin{gathered}
\mathrm{SO}_{2}(a q)+2 \mathrm{H}_{2} \mathrm{O}(\mathrm{l}) \rightarrow \mathrm{H}_{2} \mathrm{SO}_{4}(a q)+2 \mathrm{H}^{+}(a q)+2 e^{-} \\
2 \mathrm{H}^{+}+2 e^{-} \rightarrow \mathrm{H}_{2} \\
\mathrm{SO}_{2}+2 \mathrm{H}_{2} \mathrm{O} \rightarrow \mathrm{H}_{2} \mathrm{SO}_{4}+\mathrm{H}_{2}
\end{gathered}
$$

Original work on the development of a SDE featured a parallel-plate electrolyzer with a separator or membrane to keep the anolyte and catholyte compartments separate. Precious metal blacks were used as electrocatalysts [4]. Since this work was completed in the early 1980s, significant advances have occurred in electrolyzer technology principally in the area of hydrogen fuel cells. The use of state of the art polymer electrolyte membrane (PEM) electrolyzer technology was incorporated in the SDE design by Steimke et al. $[5,6]$. In the redesigned electrolyzer, $\mathrm{SO}_{2}$ dissolved in sulfuric acid is flowed to the anode while hydrogen is produced at the dry cathode. The incorporation of the PEM technology in the SDE design provides a considerable improvement in performance mainly due to a decrease in IR losses across the cell and better utilization of the catalyst layer.

Sivasubramanian et al. have studied a different operating strategy for the PEM-based $\mathrm{SDE}$ [7]. In this operational mode dry $\mathrm{SO}_{2}$ is flowed into the anode side and water is pumped through the cathode side. While this system shows improved mass transfer characteristics for $\mathrm{SO}_{2}$, the system is limited by the amount of water that diffuses from the cathode side to the anode for reaction with $\mathrm{SO}_{2}$.

While both of these approaches solve many of the engineering problems associated with the original SDE design, further development of the PEM concept is required for commercial deployment of the SDE. The more significant challenges include having membranes that exhibit good ionic conductivity and low permeability to $\mathrm{SO}_{2}$ and electrocatalysts that exhibit rapid anode reaction kinetics for the oxidation of $\mathrm{SO}_{2}$ and chemical stability to high sulfuric acid concentrations. In this article, we report the electrochemical characterization of two electrocatalysts, platinum on carbon $(\mathrm{Pt} / \mathrm{C})$ and palladium on carbon $(\mathrm{Pd} / \mathrm{C})$, which extends previously reported work with platinum and palladium blacks for the oxidation of $\mathrm{SO}_{2}$ to sulfuric acid [4].

\subsection{EXPERIMENTAL}

\subsection{CATALYST CHARACTERIZATION}

$\mathrm{Pt} / \mathrm{C}, 45 \mathrm{wt} \% \mathrm{Pt}$ ) obtained from Tanaka Kikinzoku Group and Pd supported on carbon $(\mathrm{Pd} / \mathrm{C}, 40 \mathrm{wt} \% \mathrm{Pd})$ obtained from PEMEAS, E-TEK division were tested for activity and stability using a three-electrode cell. The cell consisted of a glass vial with a Teflon cap and a water jacket. The three electrodes, which included a silver-silver chloride reference electrode, a platinum wire as the counter electrode, and a glassy carbon disk electrode (GCE), were inserted through the Teflon ${ }^{\mathrm{TM}}$ cap. To load the catalyst onto the GCE, a catalyst ink was prepared by ultrasonically blending the catalyst $(2 \mathrm{mg})$ with $1 \mathrm{~mL}$ of deionized, distilled water for $15 \mathrm{~min}$ in an ultrasonic bath. The ink $(10 \mu \mathrm{L})$ was then placed on the GCE surface. After drying, a volume of $5 \mathrm{~mL}$ of a mixture 1:20 of Nafion ${ }^{\circledR}$ solution (5 wt $\%$ from Aldrich) and methyl alcohol (Sigma) was applied on the dry catalyst to ensure adhesion on the GCE surface.

Electrochemical characterization of each catalyst material featured cyclic voltammetry (CV) and linear sweep voltammetry (LSV), which were obtained using a Bioanalytical Systems (BAS) B/W electrochemical analyzer. Sulfuric acid solutions were prepared by diluting reagent 
grade sulfuric acid (Fisher Scientific) with deionized, distilled water. Prior to the measurements all solutions were purged of oxygen by bubbling nitrogen. For tests with $\mathrm{SO}_{2}$, we continuously bubbled gaseous $\mathrm{SO}_{2}$ (Scott Specialty Gases) through the solution of sulfuric acid.

$\mathrm{CVs}$ were performed at a scan rate of $50 \mathrm{mV} / \mathrm{sec}$ and in a potential window between 1004 $\mathrm{mV}$ and $-100 \mathrm{mV}$ vs. $\mathrm{Ag} / \mathrm{AgCl}$. LSVs were performed in the potential window between $804 \mathrm{mV}$ and $104 \mathrm{mV}$ vs. $\mathrm{Ag} / \mathrm{AgCl}$ at a scan rate of $5 \mathrm{mV} / \mathrm{sec}$. The experiments were carried out at temperatures ranging from $30^{\circ} \mathrm{C}$ up to $70{ }^{\circ} \mathrm{C}$ and sulfuric acid concentrations of $30-70 \mathrm{wt} \%$. The curves were repeated until a stable performance was obtained. Both CV and LSV measurements were performed starting from the anodic potential and going in the cathodic direction.

\subsection{RESULTS AND DISCUSSION}

\subsection{ELECTROCHEMICAL CHARACTERIZATION}

Selecting the right catalyst will have an impact on the electrical efficiency by allowing the SDE to operate at conditions closer to the reversible potential (-0.158 V vs. SHE) and will have an influence in helping achieve a long-term stable performance. Two types of catalysts will be needed, one for the anode and one for the cathode. At the cathode, the electrochemical reaction [r2] occurs at higher rates than reaction [r1] and at a reversible potential close to $0 \mathrm{~V}$ vs. SHE. The catalyst of choice is platinum supported on carbon.

Compared to the cathode, the kinetics of the electrochemical oxidation of $\mathrm{SO}_{2}$ at the anode are very slow. Consequently, most of the inefficiencies of the electrolyzer arise from the low kinetics for reaction [r1]. Thus, we undertook an examination of the role of the electrocatalyst to identify a more active anode catalyst. Catalyst stability is also an important characteristic for realizing a long operational lifetime for the electrolyzer.

\subsection{CYCLIC VOLTAMMETRY}

Consecutive CVs were performed to study the stability of the catalyst and the different electrochemical reactions occurring at the surface of the electrode in the absence of $\mathrm{SO}_{2}$. This technique has previously being used in order to assess the durability of electrocatalysts in a short period of time [8]. During the CVs, the current was monitored as a function of a set potential which is varied at a constant rate. Figure 1 shows the typical consecutive $\mathrm{CVs}$ for $\mathrm{Pt} / \mathrm{C}(45 \mathrm{wt} \%$ $\mathrm{Pt})$ and $\mathrm{Pd} / \mathrm{C}(40 \mathrm{wt} \% \mathrm{Pd})$ measured at room temperature in $30 \mathrm{wt} \% \mathrm{H}_{2} \mathrm{SO}_{4}$ in the absence of $\mathrm{SO}_{2}$. Two peaks are readily observed, corresponding to the oxidation-reduction of metal and desorption-adsorption of hydrogen on the catalyst surface. The high potential peak shows the monolayer oxide formation-reduction of the catalyst layer in $30 \mathrm{wt} \% \mathrm{H}_{2} \mathrm{SO}_{4}$ is observed at around $0.75 \mathrm{~V}$ vs. SHE for Pd and $0.8 \mathrm{~V}$ vs. SHE for Pt. The low potential peak in the potential region between 0.24 and $0.1 \mathrm{~V}$ vs. SHE corresponds to the hydrogen adsorption-desorption on the catalyst surface.

In general, the area under the hydrogen adsorption-desorption peak gives an idea of the electrochemically active surface area available for reaction [9]. The difference in the hydrogen desorption peak height after consecutive cycling can be observed in Figure 2. In general, the hydrogen desorption peak is dependent on the test temperature and acid strength. In the case of the $\mathrm{Pt} / \mathrm{C}$ catalyst, the peak tends to increases until it stabilizes. The initial increase corresponds to a combination of wetting by the electrolyte of the catalyst surface and activation of the catalyst surface. For the $\mathrm{Pt}$ at a given $\mathrm{H}_{2} \mathrm{SO}_{4}$ concentration, the hydrogen adsorption peak is generally 
highest at low temperatures and decreases as temperature increases. In the case of Pd the surface area tends to decrease with each cycle until no peaks are observed. The degradation of the Pd catalyst is enhanced by temperature and acid strength, therefore making it impossible to get reliable data at temperatures higher than $50^{\circ} \mathrm{C}$.

A reduction in the peak area will indicate a reduction of active sites due to agglomeration of metal particles on the support, dissolution of metal in the electrolyte, or deactivation of active sites due to a poisoning agent. The latter can be discarded as no poisoning causing molecules are being introduced in the system during the experiment. At low temperatures higher adsorptiondesorption peaks are observed than at high temperatures. This behavior is expected as hydrogen adsorption can be assumed to follow Langmuir-type kinetics [10].

The dependence on acid strength can be more confusing. A small, almost negligible, decrease is observed in the hydrogen adsorption peak when going from $30 \mathrm{wt} \%$ to $50 \mathrm{wt} . \%$ acid concentration and low temperature $\left(30^{\circ} \mathrm{C}\right)$. However, when the testing conditions become more aggressive, a combination of higher temperatures and acid concentrations, the peak increases temporarily before starting to decrease. We attribute this behavior to a temporary increase in active surface area due to an increase in the roughening of the surface caused by the dissolution of the metal particles [10,11]. At higher temperatures and $\mathrm{H}_{2} \mathrm{SO}_{4}$ concentrations the conditions are more aggressive and rapid dissolution of the metal particles produces steadily decreasing peformance.

\subsection{LINEAR SWEEP VOLTAMMETRY}

The electrocatalytic activity of the $\mathrm{Pt} / \mathrm{C}$ and $\mathrm{Pd} / \mathrm{C}$ catalysts was investigated for the oxidation of $\mathrm{SO}_{2}$ in sulfuric acid solutions and at different temperatures. A potential window of $0.30 \mathrm{~V}$ to $1.00 \mathrm{~V}$ vs. SHE was selected to avoid the reduction of $\mathrm{SO}_{2}$ to $\mathrm{S}$, which could passivate the catalyst surface, or avoid the dissolution of the metal catalysts at higher potentials [12]. The potential current relationship is shown in Figure 3 in the form of Tafel plots obtained after several cycles until the activity reaches a maximum. It can be seen from the plots how the open circuit voltage increases as the acid strength increases. For example, potentials for $\mathrm{Pt} / \mathrm{C}$ were measured at $0.50 \mathrm{~V}, 0.56 \mathrm{~V}$ and $0.63 \mathrm{~V}$ vs. SHE in $30 \mathrm{wt} \%, 50 \mathrm{wt} \%$ and $70 \mathrm{wt}^{\circ} \mathrm{H}_{2} \mathrm{SO}_{4}$ solutions, respectively. For $\mathrm{Pd} / \mathrm{C}$, the potentials were measured at $0.59 \mathrm{~V}, 0.66 \mathrm{~V}$ and $0.73 \mathrm{~V}$ vs. $\mathrm{SHE}$, in $30 \mathrm{wt} \%, 50 \mathrm{wt} \%$ and $70 \mathrm{wt} \% \mathrm{H}_{2} \mathrm{SO}_{4}$ solutions, respectively. The improvement in the $\mathrm{SO}_{2}$ oxidation kinetics by the increase in temperature can be observed by the change in open circuit potential and the change in the Tafel slope.

As briefly mentioned above, the electrocatalyst activity reaches a maximum as the electrode is cycled. Spectroscopic experiments have demonstrated that the surface coverage of $\mathrm{SO}_{2}$ on the polycrystalline electrodes is dependent on the potential at which the $\mathrm{SO}_{2}$ is adsorbed. For example, when adsorption occurs at potentials lower than $0.55 \mathrm{~V}$ vs. SHE on a Pt electrode, the surface coverage approaches $100 \%$ [13]. However, when the adsorption potential is raised the coverage starts to decrease as some of the adsorbed $\mathrm{SO}_{2}$ oxidizes [14]. Coverage of active sites with $\mathrm{SO}_{2}$ tends to poison the catalyst, inhibiting bulk $\mathrm{SO}_{2}$ oxidation. This behavior is observed during the initial LSV measurements (data not shown), where the $\mathrm{SO}_{2}$ oxidation current is observed at relative high potentials. As the LSV is repeated, the electrocatalytic activity of the catalyst increases. Reduction of $\mathrm{SO}_{2}$ to $\mathrm{S}$ or partially reduced $\mathrm{SO}_{2}$ is responsible for the enhancement in electrocatalytic activity, as $\mathrm{S}$ is well know for changing the electrode reactivity by altering the binding characteristics of surface sites. Careful activation or adsorption of sulfur 
compounds must be controlled as when optimum surface coverage is exceeded, passivation of the active site occurs [12].

Exchange currents for $\mathrm{Pt} / \mathrm{C}$ are about three orders of magnitude higher than those of $\mathrm{Pd} / \mathrm{C}$ over the range of sulfuric acid concentrations and temperatures. In view of these results and the greater stability of the $\mathrm{Pt} / \mathrm{C}$ catalyst, we conclude that $\mathrm{Pt} / \mathrm{C}$ is a superior electrocatalyst to $\mathrm{Pd} / \mathrm{C}$ for $\mathrm{SO}_{2}$ oxidation in concentrated $\mathrm{H}_{2} \mathrm{SO}_{4}$ solutions. However, $\mathrm{Pt} / \mathrm{C}$ shows evidence of deterioration when polarized in $70 \mathrm{wt} \% \mathrm{H}_{2} \mathrm{SO}_{4}$ solution at $50{ }^{\circ} \mathrm{C}$ or higher. Operating conditions targeted for the SDE include $\mathrm{H}_{2} \mathrm{SO}_{4}$ concentrations as high as $70 \mathrm{wt} \%$ and temperatures of $80{ }^{\circ} \mathrm{C}$. Thus, further development of the anode electrocatalyst is needed to provide a material that can successfully perform in concentrated $\mathrm{H}_{2} \mathrm{SO}_{4}$ solutions at elevated temperatures.

Figure 4 shows the Arrhenius plots used to calculate the Arrhenius activation energy, ' $E_{a}$ ', for the oxidation of $\mathrm{SO}_{2}$. The graphs were prepared by plotting the logarithm of the exchange current density, ' $\log i_{o}$ ' (obtained from the Tafel plots) versus the inverse of temperature, ' $1 / \mathrm{T}$ '. In the case of $\mathrm{Pt}$, the plot results in three parallel lines where the linear slope corresponds to the minimum activation energy as described by the formula at the top of Figure 4. In the case of Pd, the plots result in two parallel lines intersected with a third one. This result may reflect the effects that Pd dissolution has on the exchange current density. However, the experiment shows that even if $\mathrm{Pd}$ was as stable as $\mathrm{Pt}$, it requires at least twice the activation energy of $\mathrm{Pt}$ for the oxidation of $\mathrm{SO}_{2}$.

\subsection{CONCLUSIONS}

The catalytic activity and stability of $\mathrm{Pt} / \mathrm{C}$ and $\mathrm{Pd} / \mathrm{C}$ were studied in $30-70 \mathrm{wt} \%$ sulfuric acid solutions and at temperatures ranging from $30-70{ }^{\circ} \mathrm{C}$. The results showed that $\mathrm{Pt} / \mathrm{C}$ exhibited very good stability and activity, whereas $\mathrm{Pd} / \mathrm{C}$ was much less stable and less active for the oxidation of $\mathrm{SO}_{2}$. $\mathrm{Pt} / \mathrm{C}$ did exhibit instability in very high $\mathrm{H}_{2} \mathrm{SO}_{4}$ concentrations $(70 \mathrm{wt} \%)$ at temperatures of $50{ }^{\circ} \mathrm{C}$ and above. Tafel plots showed lower potentials (ca. $100 \mathrm{mV}$ ) and much higher exchange currents (ca. 1000 times greater) for the oxidation of $\mathrm{SO}_{2}$ on $\mathrm{Pt} / \mathrm{C}$ compared to $\mathrm{Pd} / \mathrm{C}$. Furthermore, the activation energy for the oxidation of $\mathrm{SO}_{2}$ on $\mathrm{Pt} / \mathrm{C}$ is at least half of that on a $\mathrm{Pd} / \mathrm{C}$ surface.

\section{ACKNOWLEDGEMENTS}

This work was performed for the U.S. Department of Energy under contract DEAC0996SR18500 with funding provided by the Office of Nuclear Engineering, Science and Technology, Nuclear Hydrogen Initiative. We thank Daryl Coleman for his assistance in conducting electrochemical measurements and the E-TEK Division of PEMEAS for supplying the $\mathrm{Pd} / \mathrm{C}$ sample. 


\section{REFERENCES}

[1] J. Udagawa, P. Aguiar and N.P. Brandon, Journal of Power Sources, Article in Press.

[2] J.E. Funk, International Journal of Hydrogen Energy, 26, 185 (2001).

[3] D.D. Wagman, W. H. Evans, V. B. Parker, R. H. Schumm, I. Halow, S. M. Bailey, K. L. Churney, and R. L. Nuttall, J. Phys. Chem. Ref. Data, 11, 1 (1982).

[4] Westinghouse Electric Corporation, "A Study on the Electrolysis of Sulfur Dioxide and Water for the Sulfur Cycle Hydrogen Production Process", AESD-TME-3043, July 1980.

[5] J. L. Steimke and T. J. Steeper, "Characterization Testing of $\mathrm{H}_{2} \mathrm{O}-\mathrm{SO}_{2}$ Electrolyzer at Ambient Pressure", Westinghouse Savannah River Company, Technical Report WSRC-TR2005-00310, August 1, 2005.

[6] J. L. Steimke and T. J. Steeper, "Characterization Testing and Analysis of Single Cell $\mathrm{SO}_{2}$ Depolarized Electrolyzer", Washington Savannah River Company, Technical Report WSRCSTI-2006-00120, September 15, 2006.

[7] P. Sivasubramanian, R. P. Ramasamy, F. J. Freire, C. E. Holland, and J. W. Weidner, Int. J. Hydrogen Energy, Article in Press.

[8] H. R. Colon-Mercado and B. N. Popov, Journal of Power Sources, 155, 253 (2006).

[9] T. Toda, H. Igarashi, H. Uchida, and M. Watanabe, Journal of the Electrochemical Society, 146, 3750 (1999).

[10] M. Hara, U. Linke, and Th. Wandlowski, Electrochimica Acta, Article in Press

[11] M. T. Paffett, J. G. Beery, and S. Gottesfeld, Journal of the Electrochemical Society, 135, 1431 (1988).

[12] C. Quijada, A. Rodes, J. L. Vázquez, J. M. Pérez, and A. Aldaz, Journal of Electroanalytical Chemistry, 398, 105 (1995).

[13] I. R. Morales, M. Weber, and F. C. Nart, Electrochimica Acta, 42, 617 (1997).

[14] C. Quijada, A. Rodes, J. L. Vázquez, J. M. Pérez, and A. Aldaz, Journal of Electroanalytical Chemistry, 394, 217 (1995). 

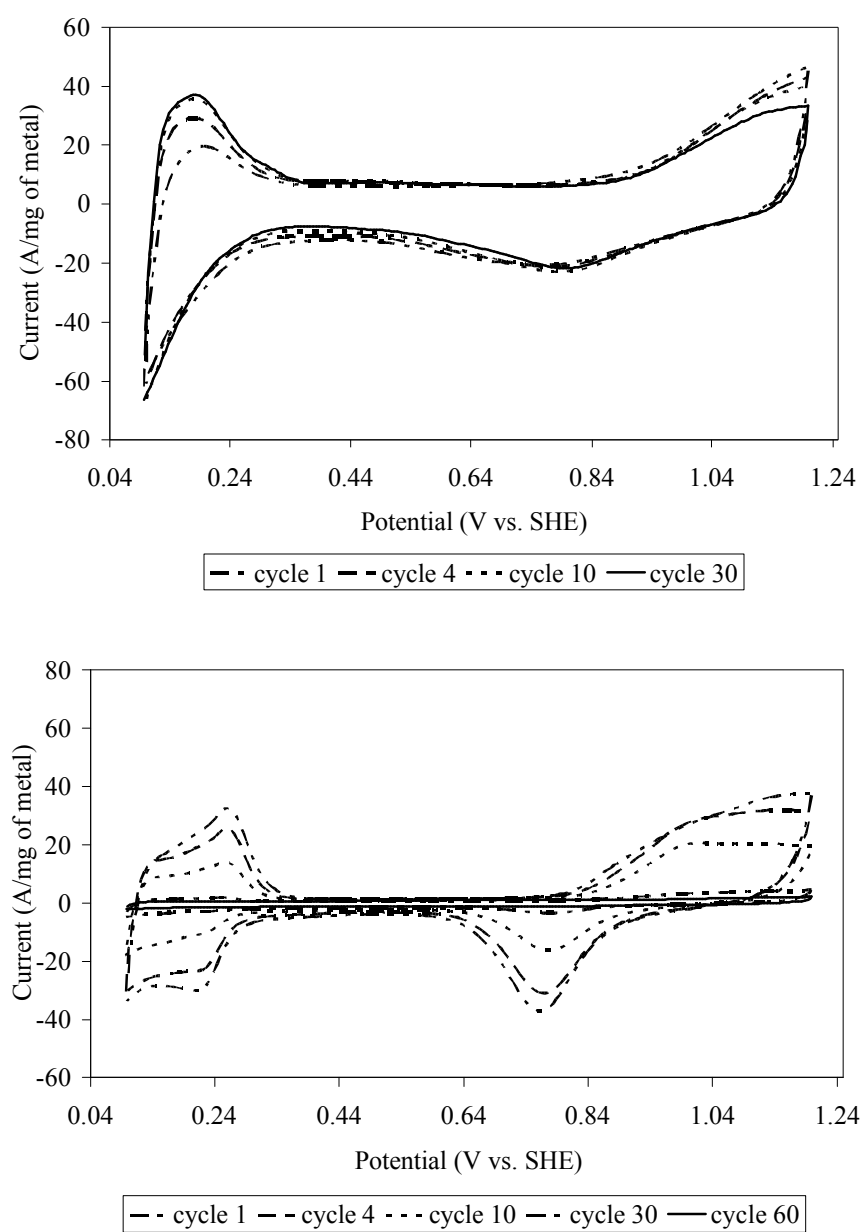

Figure 1. Typical cyclic voltammograms after consecutive cycling for $\mathrm{Pt} / \mathrm{C}$ (top) and $\mathrm{Pd} / \mathrm{C}$ (bottom) in $30 \mathrm{wt} \% \mathrm{H}_{2} \mathrm{SO}_{4}$ purged with $\mathrm{N}_{2}$ at room temperature. 


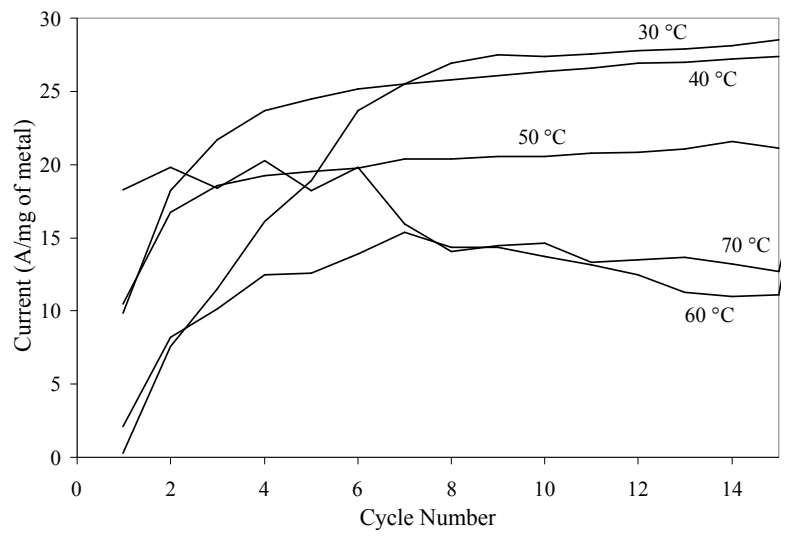

(a)
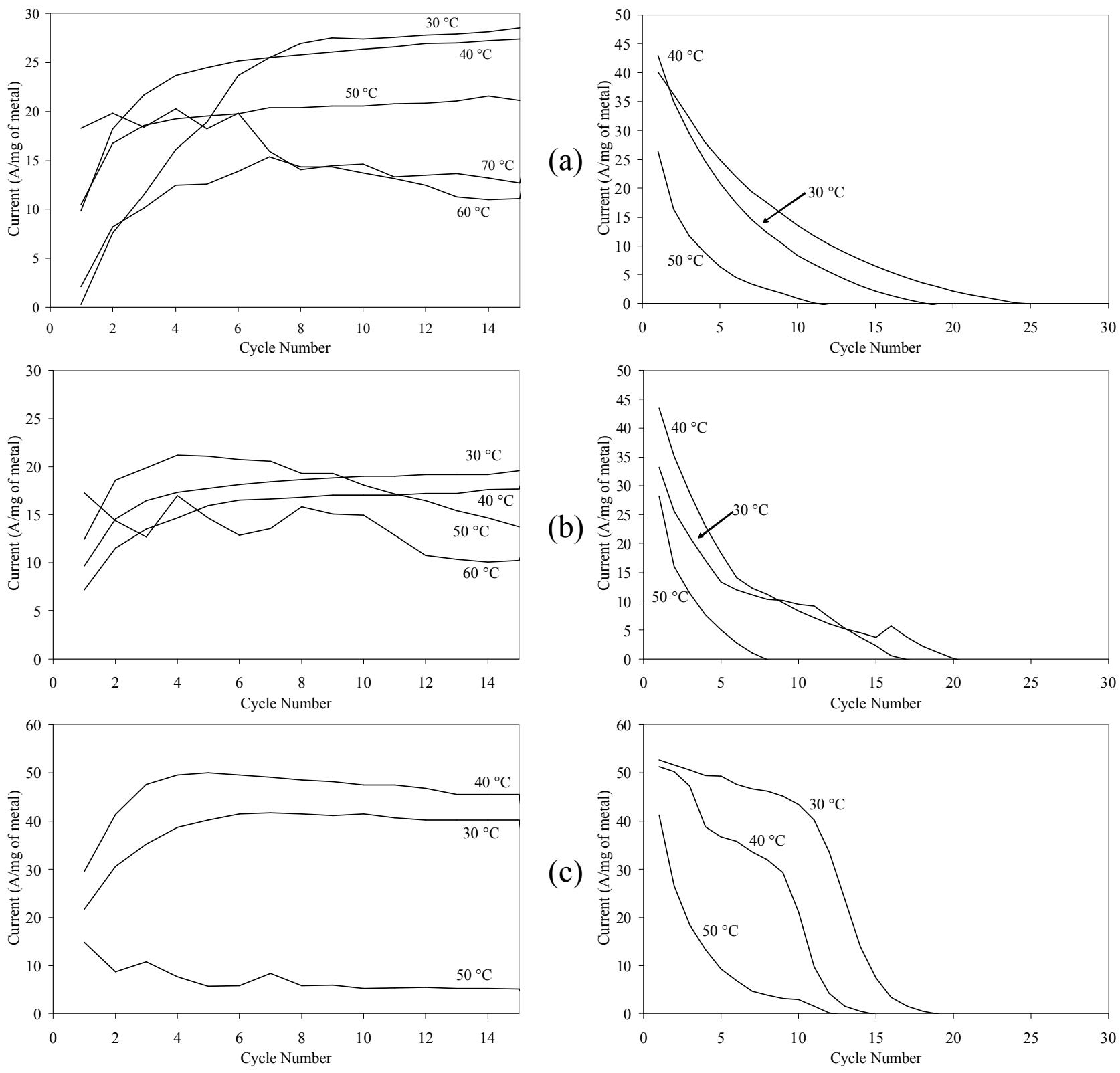

Figure 2. Hydrogen desorption peak height after consecutive cycling for $\mathrm{Pt} / \mathrm{C}$ (left) and $\mathrm{Pd} / \mathrm{C}$ (right) in (a) $30 \mathrm{wt} \%$, (b) $50 \mathrm{wt} \%$, and (c) $70 \mathrm{wt} \% \mathrm{H}_{2} \mathrm{SO}_{4}$ purged with $\mathrm{N}_{2}$ at room temperature. 

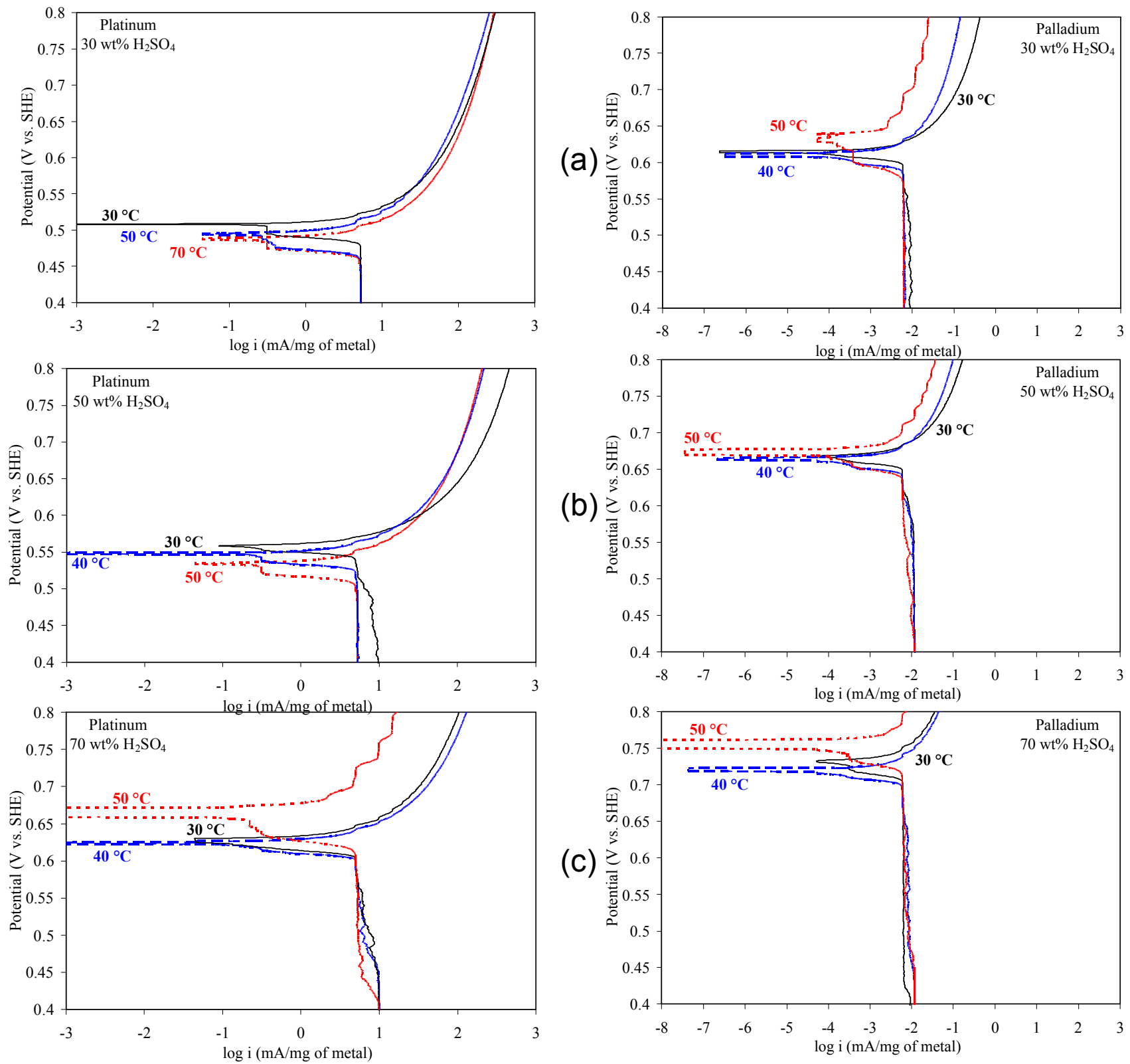

Figure 3. Tafel plots for $\mathrm{SO}_{2}$ oxidation on $\mathrm{Pt} / \mathrm{C}$ (left) and $\mathrm{Pd} / \mathrm{C}$ (right) in (a) $30 \mathrm{wt} \%$, (b) $50 \mathrm{wt} \%$,

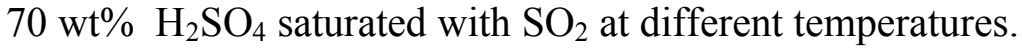



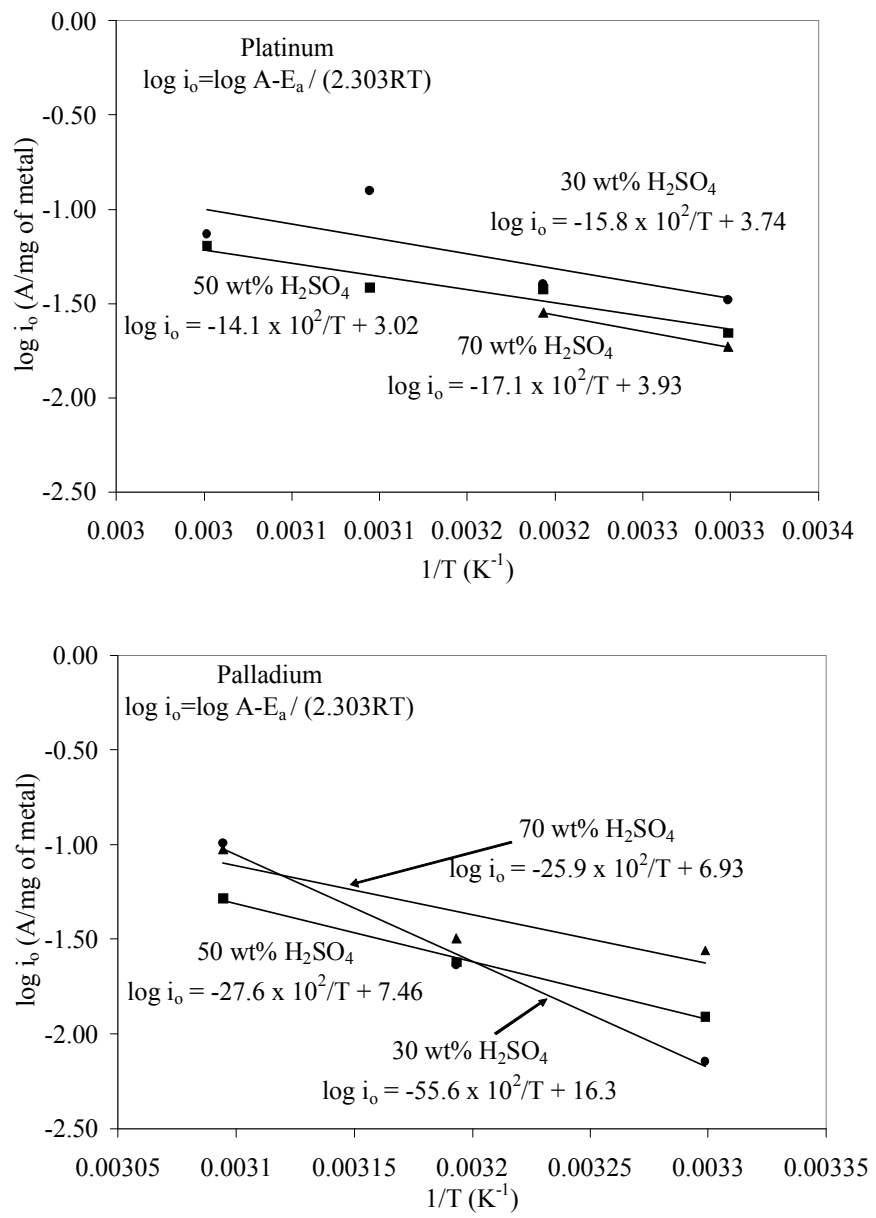

Figure 4. Arrhenius plots for $\mathrm{SO}_{2}$ oxidation on $\mathrm{Pt} / \mathrm{C}$ (top) and $\mathrm{Pd} / \mathrm{C}$ (bottom) in $30 \mathrm{wt} \%, 50 \mathrm{wt} \%$ and $70 \mathrm{wt} \% \mathrm{H}_{2} \mathrm{SO}_{4}$ saturated with $\mathrm{SO}_{2}$ at different temperatures. 